\title{
RUSSIA'S FUTURE NEEDS FOR CAPITAL
}

\author{
By Samdel McRoberts, \\ Vice President, National City Bank, New York City.
}

No individual or collection of individuals can undergo a great test of strength and come out of it the same as before the ordeal. If the draft upon the vitality is too great, the result is a lower order of life, or even death. On the other hand, if there is sufficient strength to successfully meet the crisis, the contest brings added physical ability and a quickened spirit. The great war in Europe has set all minds to considering the effect upon civilization, and the utility, if there is any, of war in the abstract. Whether it is an unmitigated evil, to be borne as one of the defects in human affairs, or an evil that must be endured that good may result, is a question that will continue to be debated. When we see the high civilization of England being cut down from the top, or Germany's peaceful conquest of the world abandoned for a military conquest, war takes on the aspect of disease and a menace to the constructive forces of civilization. When we turn to the case of Russia, the matter is not so clear. Dean Swift once said, in reference to his critics, that unless the asses ate off the ground leaves of certain plants, they would never grow tall, and certainly Russia has had a tendency to sprawl. Occupying one-seventh of the land of the globe, she includes a wide diversity of people, and is not entirely a homogeneous nation. National spirit has been lacking, her circulation has been slow. Individualism and personal initiative in the great mass of her population have been at a low ebb. It is idle to attribute this condition to the character of its government, for no government has failed to reflect the status of its people for any great length of time. This internal condition of Russia has been improving, very rapidly so during the last ten years, but the effects already observable seem to indicate that the war is going to accomplish for Russia within the few years of its duration what would have ordinarily required many years. Already the greatest social evil in Russia, drunkenness, has disappeared, with startling effect upon the economic and moral status of the people. The Russians are united in this titanic struggle, and a genuine 207 
national spirit is in evidence. Old customs are being broken up, and a new experience brought to every individual in the Empire. No final judgment can be formed at this time, but it would appear that the quickening of the spirit of Russia may eventually be considered worth its terrible cost.

\section{Russia's Problem in Financing the War}

In 1914 , at the commencement of the war, Russia had a rapidly increasing foreign trade, which produced a credit balance for meeting the service of her foreign loans. Her public debt was decreasing, and was largely offset by revenue-producing property owned by the state. Direct taxation throughout the Empire was declining year by year. The financial position was sound. The government debt, considered on a per capita basis, was the lowest of any European country, and if considered in relation to its natural resources, presented an even more favorable comparison. This advantageous financial position and the latent wealth of her resources did not save Russia, however, from the severest possible difficulties in financing the war. Internal loans were promptly forthcoming for internal needs, which were the greater part of the demands of the war, but her ports were closed and commercial intercourse with the world practically cut off. Not being able to export goods, and not owning foreign securities, Russia found herself practically without foreign resources. The unprecedented character of the war imperatively demanded huge expenditures of materials, which her own manufacturers were unable to supply, even if the raw products could be obtained within her own borders. The enormous depreciation of the rouble exchange, inevitable under these circumstances, intensified the difficulties in many ways. The situation could be met only by foreign loans. Russia and the basis of her credit were little known or understood in the United States, and therefore her requirements have been financed by England as a war measure, excepting negligible amounts furnished by this country and Japan. It thus turned out that the one country in Europe best able to stand the strain of a great war, both as regards men and natural resources, was for its immediate needs in the weakest financial position. This has all made a deep impression in Russia. What individual economists and thoughtful business men have been thinking and saying has suddenly become the conviction of the entire 
country. The people are united in the purpose to develop, completely and as rapidly as possible, the natural resources of their country.

The public debt has increased from $\$ 4,500,000,000$ in 1914 to about $\$ 12,000,000,000$ at the present time, and the annual debt charge from $\$ 218,000,000$ to about $\$ 600,000,000$. These figures will continue to increase until the end of the war. Russia faces the recessity of raising immensely greater revenues than she had ever contemplated as necessary. To do this the wealth of the nation must be rapidly increased, and the ability of the individual to pay taxes, greatly augmented.

These three factors in the Russian situation-the quickening of the Russian spirit, the realization of the economic follies of the past and the importance of commercial and financial independence, and the spur of necessity - are combining to bring about a great program of development throughout the Empire. It is everywhere being discussed and advocated where thoughtful Russians congregate. It is presented in the reports of the ministers, made the topic of speeches in the Council of the Empire and the Duma, and is a recurring subject in the daily press. The government has announced that it receives almost daily from all parts of Russia, from members of the legislature, from noblemen, priests, peasants, civil service employes, officers, merchants. physicians, lawyers, workers, etc., suggestions as to how Russia should solve her financial problems after the war and that all these suggestions breathe lofty patriotism and faith in the strength and splendid future of the country. Plainly the significance of industrial development for the future of the country is felt and appreciated everywhere throughout Russia.

\section{The Extent and Importance of Her Natural Resources}

The basis, in the way of natural resources, for Russia's economic development is very broad. The population is officially stated to be $174,000,000$, the largest of any country, except China and India, with a normal increase of about 3,000,000 per year. The land area is four times the area of Europe and about three times the area of the United States and includes every variety of territory, from the highest mountain ranges to the most fertile of alluvial plains. The climate ranges from arctic to the semi-tropical of Turkestan, TransCaucasia and the Crimea. The country can produce within its own 
area all the essentials to modern civilization. For agriculture, it has the most extensive acreage of first-class farm land anywhere found on the globe. It has about fifty per cent of the timber north of the equator. It has large known deposits of iron, manganese, coal, oil, copper, platinum, gold and silver; while minerals of lesser importance, such as asbestos, graphite, lead, mercury, salt, tin and zinc, are being produced. Eighty-five per cent of the population live in the country. The remaining 15 per cent make up the population of the cities, of which there are over two hundred in the Empire. Sixtyfive of these cities have a population of over fifty thousand, and twenty-four a population in excess of one hundred thousand. One hundred and fifty-three million of the $174,000,000$ inhabitants live in Russia in Europe, which in area is only one-sixth of the Empire. Twenty-one million occupy Siberia and Central Asia. Siberia, more than one-half of the Empire, has only ten million of people.

In many ways Russia, today, presents an enlarged picture of the United States at the close of the Civil War, with its population then occupying the territory east of the Mississippi River, and with a great unoccupied and undeveloped public domain lying beyond. Just as the United States then turned to the development of its public lands and mineral deposits in the West, and to the organization of industries in the East, Russia is now taking stock of her great timber resources, her fertile unoccupied lands, the hidden treasures of her mountain ranges, and turning her attention to the organization of industries in her more thickly populated sections, for only in this way can she produce the greatly increased wealth which will be necessary to enable her to meet her war obligations and give her an increasingly greater position in world affairs. The increase of grain production by the opening up of new farms and more intensive cultivation, will require capital, but not more than the surplus wealth of the present agriculture will supply. The basis for this extension is made apparent by the fact that in 1913 Russia planted to cereals alone over $215,000,000$ acres. Of this, $82,600,000$ acres were planted in wheat, yielding $1,024,000,000$ bushels. The average yield for winter wheat was $15 \frac{2}{3}$ bushels per acre, and for spring wheat $11 \frac{1}{\mathrm{a}}$ bushels per acre. This was a good year in Russia, and might be compared with the same year in the United States, when there were planted $49,601,000$ acres, producing 15.2 bushels per acre, or a total of $753,000,000$ bushels. 
These figures demonstrate that there are ample financial resources for the extension of Russia's agriculture, such as the opening up of new territory, the improving of live-stock, the planting of orchards, the developing of fertilizers, and all those things directly incidental to a larger acreage and more scientific cultivation; but there are incidental tasks which will require large units of capital that cannot be taken directly from the agricultural community. The country has insufficient facilities for the economical transportation and storage of grain; and up to the present time the losses from this source have been on a tremendous scale. However, at the outbreak of the war the government had under way a construction-program for eighty-one elevators, of a capacity of 34,860 ,000 bushels; and an additional program of seventy-seven elevators, with a capacity of $37,650,000$ bushels, has been agreed upon and authorized. But even as now planned, the elevator system is by no means adequate, and the whole system of grain handling and transportation will need radical reformation.

\section{Cotton Fruits and Meat Proddcts}

Russia today is producing in Central Asia more than two-thirds of the cotton required by Russian spindles. To grow her total requirement, and develop an export industry, necessitates the extension of the irrigated territory in Turkestan. The climate, soil and water are there, and even the engineering has been done to a large extent, so that all that will be required to make Russia independent of foreign production will be capital for the extension of an existing and successful industry. Even when this is accomplished, the need for capital will be only increased, as Russia will occupy a geographically favorable position for supplying the great cotton textile demands of Central Asia; and if sufficient cotton can be produced, there is no economic reason why her textile industry should not be correspondingly extended. This reasoning applies also to the other textiles. Today large quantities of flax and wool are exported in the raw state. To convert the export of these raw materials into manufactured products will eventually call for large expenditures.

The Crimea, the Caucasus and Turkestan are in every way adapted for the growing of all kinds of fruits, but the fruit industry cannot be extended and the products marketed without the establishment of refrigeration service, which is today practically non- 
existent in Russia. This would also apply to the dairy and poultry industries of Siberia. The raising of food animals is an important activity throughout the Empire; and Russia has more sheep and goats than the United States, nearly as many cattle, and about onefourth as many hogs. Recently much attention is being given to scientific breeding, and some progress has been made in feeding for food results, but there is no organization of the industry beyond the farms. Australia can put mutton on the market in Russia cheaper than the home-grown product can be obtained, because in Russia all animals are sent as live freight to the point of slaughter; the economies from centralized slaughtering plants and the handling of the dressed product under cold storage having not been yet introduced.

\section{Opportunities in Lumbering and Mining}

Russia is practically the only country in Europe having an excess of timber over and above its own requirements. While Sweden, Norway and Austria-Hungary still have a surplus; of recent years it has become so small as to be almost negligible. Russia is the great timber reserve of Europe, and while in 1913 she exported timber to the amount of $\$ 84,000,000$, she still has not begun to realize upon the possibilities in her timber trade. The Englishman's definition to the effect that timber was "an excrescence growing upon the earth, chiefly useful for paying off the debts of one's ancestors," will be particularly applicable to the Russian forests. The demand for timber in Europe following the war must necessarily be greatly in excess of normal. It is stated that afier the earthquake in Messina, in 1913, Italy's timber import increased 22 per cent over the average for the previous five years. If this is any indication, Russia will have a wonderful opportunity to realize the latent wealth of its forests. This will mean an enormous outlay of capital for the building of railroads, port facilities, steamships, sawmills, pulp mills, and all of those things incidental to the manufacture and transportation of timber products.

Russia has already taken steps to attract foreign capital to the mining industry, by reforming its taxation laws and granting more liberal concessions, and by facilitating, as well as granting government aid to, the importation of improved mining machinery. She will necessarily continue to stimulate in every way the production 
of gold and the other precious metals. Her known copper deposits make her practically independent of international production, and the best authorities agree that her mineral fields have not begun to be exploited.

\section{The Need for More Railways}

One of the chief essentials underlying the whole problem of economic progress and realization of national energy and labor is the expansion of the railway net of Russia. An adequate railway system is absolutely indispensable for bringing out the natural resources of any country, and the extension of the railway system of Russia cannot be economically accomplished without a full development of her metallurgic industries. Even before the war there was a growing feeling in Russia that her railway system was not commensurate to the economic needs of the country; and since that time this has become too self-evident to be questioned. The total railroad mileage in Russia is 47,000 miles. An idea of what this means, in the way of unserved territory, can be obtained by comparing it to the railway mileage of the United States, which country, while only one-third as large, has 260,000 miles of road. This means that Russia, on the basis of square miles, has only 5 per cent, and on the basis of population, only 10 per cent, of the railway mileage of the United States. This has been fully discussed, and its importance understood, in Russia; and it seems to be considered as the initial problem to confront the country at the close of the war. The government commission has already examined and sanctioned the building of a total of 16,776 versts, at an estimated cost of $1,466,000,000$ roubles, and at the beginning of the present year this program was further enlarged by the sanctioning of an additional 3,000 versts, at a cost of $266,000,000$ roubles. So the country is already officially pledged to the construction of about 20,000 versts, or 13,333 miles, while projects are under consideration for official action that will bring this up to about 17,000 miles, at an estimated cost of over a billion dollars.

It is the declared purpose of the government, provided capital can be obtained from the international money markets, to enter upon a policy of construction that would produce approximately 5,000 miles per year. It is highly improbable that any such extensive program can be carried out, with the result that only those 
projects presenting the most attractive opportunities to capital will be taken up. What this means to the steel industry in Russia is apparent when we consider that each mile of road requires approximately two hundred tons of metal. Furthermore, the existing railroads, while well constructed, are designed to bear only a light unit of transportation. With long hauls and heavy traffic, Russia is being forced to the large unit of transportation adopted in this country, which will require re-laying the existing roads with heavier rails and the strengthening of all right-of-way structures. It will be prohibitively expensive for Russia to import railway metal, owing to the high cost of transportation, therefore the pace of her railway development will be determined not only by the readiness with which capital is obtained, but by the extent and speed of the enlargement of the steel industry. The country is fairly well supplied with coal, and it has iron ore in very great abundance. At the present time the development of both coal and iron is by unrelated and comparatively small units; adequate and economical results will not be obtained until the whole industry is organized along comprehensive lines and the raw materials linked together by special transportation facilities.

\section{The Steel and Coal Industries}

In addition to soft coal, which Russia is seeking to conserve for the steel industry, the largest anthracite deposits in Europe are located in European Russia. The production of anthracite has been comparatively small. During the year ending July, 1914, the output was only about five million tons, although there was a shortage of fuel at Moscow, but 650 miles distant. The production of these coal fields has been by one-shaft mines, by small companies. There is no resident mining population, the work being done almost entirely by farmers coming to the mines at the season of the year when they are not employed upon their farms. As a result the cost of producing anthracite is about twice what it is in this country. The government has recently adopted the policy of conserving soft coal for the steel industries, and to that end has made regulations requiring the use of anthracite for all industrial boilers and railroads, after a certain date. This will greatly stimulate the use of anthracite and necessitate the placing of the mining upon a more comprehensive and economical basis. 
The foregoing are simply isolated illustrations of the needs for capital in Russia. There are other important ones, such as hydroelectric development, municipal and interurban transportation, harbor works, canals and ship-building, and possibly still more important is the additional general working capital necessary to finance the incidental commerce and trade that is a part of a great progressive movement.

\section{The New Russia}

Whether this program of industrial development will be undertaken or carried out, of course, depends primarily upon the temperament and capacity of the Russians themselves. It might be said that, being to some extent Oriental, they do not have the same attitude towards business as do Americans or other Europeans; that the status of the laws, their adherence to communal practices, and the restrictions upon individual activity, will be insurmountable barriers. This is not borne out by observation in Russia under the present conditions. They are a far-North people, and have the characteristic vigor and activity of all European races. They are breaking up community of ownership and getting away from the socialistic doctrines that we in this country are reacting to from a too intense individualism. While the citizens of all countries are very much prone to look upon themselves as different from, and incidentally better than, the people of other lands, the real fact remains that all peoples are essentially the same and respond in similar manner to physical and ethical influences. The conditions in Russia are much the same as those that preceded the great industrial rise in this country, and for the same reasons that it occurred here, we may confidently expect an era of individualism and materialism to be inaugurated in Russia. 